Covered in: Web of Science (WOS); EBSCO; ERIH+; Google Scholar; Index Copernicus; Ideas RePeC; Econpapers; Socionet; CEEOL; Ulrich ProQuest; Cabell, Journalseek; Scipio; Philpapers; SHERPA/RoMEO repositories; KVK; WorldCat; CrossRef; CrossCheck

2020, Volume 11, Issue 3, pages: 115-128 | https://doi.org/10.18662/po/11.3/202

\section{The Impact of Global Tensions on the Economic and Financial Cycle in Romania}

\section{Andreea MURARU1}

${ }^{1}$ The Bucharest Academy of Economic Studies, Bucharest, Romania, andreea.muraru@ie.ase.ro

\begin{abstract}
In this paper I investigated the impact of global financial tensions (approximated by the common factor in the evolution of market volatility indexes in the US and the Euro area - VIX, VSTOXX, VFTSE) on the Romanian financial and economic cycle. As measures for the financial cycle I used multiple indicators following the literature on the subject (credit variables, bond yields, house prices and GDP) and I investigated the impact of global tensions on each of the selected variables and also on an aggregate measure of the financial and economic cyclical position, which I built by applying factor analysis. The influence of global tensions was studied by use of wavelet coherence, concordance indicators and historical decomposition. The results showed important correlations of global tensions with the selected variables and also with the cyclical position indicator. Moreover, the concordance indicator (computed by the use of Bry-Boschan algorithm for quarterly series on the band-pass filtered series) showed that indicators were in the same cyclical position with the global financial evolutions most of the time (the indicator varying between 54 percent and 70 percent of the time), therefore the local cyclical position (built out of the considered indicators) coincided with the cycle of global tensions in 60 percent of cases. Historical decomposition was performed in Bayesian VARs estimated for each of the variables and the global tensions indicator. The results showed a great impact, dominant at times, of global shocks on the evolution of the selected variables and on the cyclical position indicator.
\end{abstract}

Keywords: financial cycle; global tensions; factor analysis; comovement; historical decomposition.

How to cite: Muraru, A. (2020). The Impact of Global Tensions on the Economic and Financial Cycle in

Romania. Postmodern Openings, 11(3), 115-128. https://doi.org/10.18662/po/11.3/202 
The Impact of Global Tensions on the Economic and Financial Cycle in ... Andreea MURARU

\section{Introduction}

The importance and relevance of this study for postmodern studies comes, on one hand, from its focus on a feature of the globalized international financial markets. Specifically, this study investigates the external influence on the financial and economic developments in Romania, analysed through cycles. In the context of globalized markets, the evolutions on the domestic markets cannot be seen as independent or as evolving only on account of local influences, but as part of the regional and international, global, market.

On the other hand, the global economy can be seen as a network of complex interdependences among countries (Dées \& Gales, 2019) which is another important research feature of postmodern studies. Financial and economic evolutions among countries are therefore interconnected, domestic markets receive the influence of the developments that take place on the major international markets and consequently react to it, especially in times of distress, as it was the case during the recent economic and financial crisis (when researcher started to study more intensely this subject).

As shown in literature on financial cycles (WGEM Team, 2018) the economic and financial cycle might co-move at country level and cycles might manifest synchronicity among countries. In a previous investigation (Muraru, 2019) of these types of synchronicities in Romania and other EEMs (Poland, Czech Republic and Hungary) I reached the conclusion that there is a common cycle among these countries. Therefore, the research in this paper is a continuation of my previous study, focusing on the impact of global tensions on Romania's economic and financial cycle. Like all emerging economies, Romania is also largely influenced by the developments on external markets, thus, it is not uncommon to assume that its economic and financial cycle might also have externally induced components. Moreover, previous evidence suggested that co-movement characterises the financial cycles of EEM countries, consequently, their synchronicity might be determined by a common global influence. As representative for the global tensions I considered indexes of realized market volatility in the US and the euro area. Even though discussed in the economic literature and financial analyses, a formal quantitative analysis of the impact of external tensions on the Romanian economy was not developed, so this research is a needed starting point for filling this gap. The methodology that I used for this study is similar to the rich literature on financial and economic cycles (to which it belongs), but it also has an element of novelty as I considered more appropriate the use of factor 
analysis than principal component analysis in determining the cyclical component because I regard the nature of a latent component to be much closer to the economic concept of common cycle.

\section{Problem Statement}

The literature on financial and economic cycles is abundant and has flourished especially after the start of the global financial and economic crisis. A growing stream of literature is related to the macroprudential importance of financial cycles - the Basel III regulations regarding the countercyclical capital buffer make explicit reference to credit gap, measured as the difference between the credit to GDP ratio and its HP long-run trend. From the large number of studies I mention Gadanecz and Jayaram (2016) which reviews the work on macroprudential policy and indicators to be used, as well as some studies that approach the topic of financial cycles from a policy perspective (Benes et al., 2016; Borio, 2014; Bruno and Shin, 2015; Drehmann et al., 2011).

Another line of research concerning financial cycles concentrates on the most appropriate method of identifying cycles and on analysing their concordance among countries or their common movement with the economic cycle. The two most commonly used methods for constructing cycle measures are different types of filters and turning point analysis (see for example Claessens et al. (2011), Claessens et al. (2012), Haavio (2012), Aikamn et al. (2015)). There are also studies, like Drehmann et al. (2012), which make use of both turning point analysis and band-pass filters for identifying cycles. The common movement either among countries or between the economic and the financial sector is investigated in a large number of studies applying a multitude of techniques: multivariate structural model (Rünstler \& Vlekke, 2016), multi-level factor model (Breitung \& Eickmeier, 2016), synchronicity index (Comunale, 2017), wavelet coherence (WGEM Team, 2018), principal component analysis, similarity and wavelet coherence (WGEM Team, 2018; Kunovac et al., 2018).

There is also a stream of research that focuses on the global financial cycle (Aldasoro et al., 2020; Boz \& Tesar, 2019; Miranda-Agrippino \& Rey, 2020a) some of them investigating the impact that mostly US monetary policy has on economies (Dées \& Gales, 2019; Miranda-Agrippino \& Rey, 2020b).

In this paper I adopted an approach similar to that in WGEM Team, (2018) and Kunovac et al. (2018) in the sense that I also used the band-pass filter to isolate the cycles and the concordance measure was computed after 
applying the Bry-Boschan algorithm for quarterly series. One difference in terms of methodology is that I didn't make use of principal component analysis when building an aggregate measure of cycles because I considered factor analysis closer to the meaning I attributed to the constructed variables.

The literature on financial and economic cycles in Romania is scarce. Usually studies concentrate on advanced economies because of longer data ranges. Still, even though there are some limitations because of the short data span, the studies regarding financial and economic cycle could bring important results.

\section{Research Questions/Aims of the research}

In this paper I tried to identify if there is co-movement between a measure of global tensions that I created starting from three realised market volatility indexes (VIX, VSTOXX, VFTSE) representative for the US and the EU and the financial and economic cycle in Romania. For identifying the financial cycle I used multiple indicators following the literature on the subject and the aim of the research was to investigate the impact of global tensions on each of the selected variables and also on an aggregate measure of the financial and economic cyclical position, which I build by applying factor analysis. The choice of factor analysis is motivated by the fact that it allows to identify the latent component that induces the common movement in the investigated series.

The dataset comprises 4 quarterly data series: credit to households, house prices, 10 year government bond yields and GDP ${ }^{1}$. The time span covered is 2004q1-2018q3 and the data sources are as follows: the data on loans was collected from the National Bank of Romania website; house prices were obtained from National Statistical Institute and the NBR; the yields on 10 year government bonds were downloaded from the NBR website and extended backwards through regression on long term interest rates for convergence purposes (source ECB, SDW) and ROBOR $12 \mathrm{M}$ (source NBR). Data entered the analyses in real terms, deflated with the GDP deflator and in logarithms, with the exception of indexes and interest rates.

1 Initially the set of variables also included credit to non-financial corporations and equity, but in factor analysis they proved to have very high uniqueness, therefore their evolution was mostly influenced by specific factors and not common cycles. 


\section{Methodology}

The measures of global financial tensions and local cyclical position were determined by applying factor analysis. The goal of this multivariate data analysis technique is to identify the latent factors that generate the common movement of the considered variables. Therefore, the original data series are explained in terms of common factors and unique factors elements specific for the evolution of a particular variable. In matrix form, the model of factor analysis is:

$$
\mathrm{X}-\mu=\mathrm{AF}+\mathrm{U}
$$

where: $\mathrm{X}=\left(\mathrm{x}_{1} \mathrm{x}_{2} \cdots \mathrm{x}_{\mathrm{n}}\right)^{\prime}$ is the vector of $\mathrm{n}$ initial variables, $\mu=$ $\left(\mu_{1} \mu_{2} \cdots \mu_{n}\right)^{\prime}$ the mean of the variables, $A=$ matrix of factor coefficients (intensities), $F=\left(\mathrm{f}_{1} \mathrm{f}_{2} \cdots \mathrm{f}_{\mathrm{n}}\right)^{\prime}$ the $p$ common factors $(\mathrm{p}<\mathrm{n})$ and $\mathrm{U}=$ $\left(u_{1} u_{2} \cdots u_{n}\right)^{\prime}$ a vectors of unique factors for each initial variable.

There are some assumptions of the factor model: (i) common factors are uncorrelated, have zero mean and unit variance $\left(\operatorname{var}\left(f_{i}\right)=1\right)$; (ii) unique factors are also uncorrelated and of zero mean, but with a different variance $\left(\operatorname{var}\left(u_{i}\right)=\psi_{i}\right)$; (iii) Common factors are not correlated with the unique factors $\left(\operatorname{cov}\left(f_{i}, u_{i}\right)=0, \forall i, j\right)$.

Consequently, the variance of a variable $x_{i}$ can be written as:

$$
\operatorname{var}\left(x_{i}\right)=\sigma_{i}^{2}=\alpha_{i 1}^{2} \operatorname{var}\left(f_{1}\right)+\alpha_{i 2}^{2} \operatorname{var}\left(f_{2}\right)+\cdots+\alpha_{i p}^{2} \operatorname{var}\left(f_{p}\right)+
$$

$\operatorname{var}\left(u_{i}\right) \quad(2)$

which can be expressed as:

$$
\sigma_{i}^{2}=h_{i}^{2}+\psi_{i}
$$

where $h_{i}^{2}=\alpha_{i 1}^{2}+\alpha_{i 2}^{2}+\cdots+\alpha_{i p}^{2}$ is called communality and it represents the share of variance attributed to common factors, whiled $\psi_{i}$ is the uniqueness - the variance attributed to elements that are specific in the evolution of a series. Communality and uniqueness sum to 1 , for standardised variables

For identifying the cycles I used the widely spread method of filtering, namely the band-pass filter. The filtering bounds were established at 8 and 60, for a median length of financials cycle of 15 years Drehmann et al. (2010). A length of 30 years for the financial cycle could not have been considered in the analysis given the relatively short sample. The same frequency band was used for GDP (in spite of the fact that traditionally, the economic cycle has a length between 2 and 8 years) because otherwise the

${ }^{2}$ As the research is a continuation of a previous project, parts of the theoretical exposure of methodology (factor analysis, filters and BBQ algorithm) are similar to Muraru (2019). 
series could have been uncorrelated by construction (WGEM Team, 2018). The index of similarity between the financial variables and global tensions was calculated after identifying the peaks and troughs in the series with the Bry-Boschan algorithm for quarterly series.

Another method of studying the impact of global tensions was historical decomposition. This method (applied in this case in Bayesian VARs) allows for the identification of the shocks' contribution to the observed data series by decomposing the series. The MA representation allows the VAR, through successive substitutions, to be written as:

$\mathrm{y}_{\mathrm{t}}=\sum_{\mathrm{i}=0}^{\mathrm{t}-1} \varphi_{\mathrm{i}} \vartheta_{\mathrm{t}-\mathrm{i}}+\mathrm{A}_{1}^{\mathrm{t}} \mathrm{y}_{0}+\cdots+A_{\mathrm{p}}^{\mathrm{t}} \mathrm{y}_{-\mathrm{p}+1}$

and therefore:

$$
\mathrm{y}_{\mathrm{jt}}^{\mathrm{k}}=\sum_{\mathrm{i}=0}^{\mathrm{t}-1} \varphi_{\mathrm{jk}, \mathrm{i}} \vartheta_{\mathrm{k}, \mathrm{t}-\mathrm{i}}+\alpha_{\mathrm{j} 1}^{\mathrm{t}} \mathrm{y}_{0}+\cdots+\alpha_{\mathrm{jp}}^{\mathrm{t}} \mathrm{y}_{-\mathrm{p}+1}
$$

is the contribution of the $\mathrm{k}^{\text {th }}$ structural shock to the $j^{\text {th }}$ component series of $y$ - its part of historical decomposition (Lutkepohl, 2011).

Wavelet coherence illustrates the co-movement of series in a dynamic manner - both in time and at different frequencies of the cycle, as wavelet analysis decomposes the data series in its periodic elements, showing how they evolve in time. The continuous wavelet transformation implies the projection of the time series on a wavelet function. As in most economic applications, I used the Morlet wavelet. For details on wavelet analysis see Cazelles et al. (2008), Aguiar-Conraria et al. (2008), Aguiar-Conraria and Soares (2014).

\section{Results}

As mentioned before, the computation of the financial tensions variable was done through factor analysis applied on three indexes that show the evolution of realised market volatility in US and Euro area, namely: VIX, VSTOXX, VFTSE. As expected on account of the high correlation among the three indexes, one factor explains most of the variables' evolution (Table 1).

Table 1. Factor analysis - global tensions

Source: Author's own conception

\begin{tabular}{lll}
\hline & Loadings & Uniquness \\
\hline VIX & 0.95 & 0.11 \\
VSTOXX & 0.99 & 0.02 \\
VFTSE & 0.97 & 0.06 \\
\hline
\end{tabular}




\subsection{Concordance indicators}

I have further analysed the concordance between the global tensions and the cyclical movements in the considered financial variables: credit to households, house prices, 10y bonds yield and GDP (Table 2). Cycles were extracted with the band-pass filter. The concordance indicator shows the synchronicity of cycles in the financial variables and the global tensions by counting the moments when the two analysed series are in the same phase of the cycle relative to the total number of observations. The phases of the cycle were dated with the Bry-Boschan algorithm adapted for quarterly data series (BBQ) and I used the Matlab code provided by Engel (2019). As previous research showed (Muraru, 2019) there is relatively high concordance between the economic and financial cycle for Romania, therefore I have built an aggregate measure of the financial and economic cyclical position, by applying once again factor analysis, and then computed the concordance indicator after applying the BBQ algorithm.

Table 2. Concordance indicator between global tensions and selected variables

Source: Author's own conception

\begin{tabular}{ccccc}
\hline $\begin{array}{l}\text { Credit to } \\
\text { households }\end{array}$ & $\begin{array}{c}\text { House } \\
\text { prices }\end{array}$ & $\begin{array}{c}10 Y \\
\text { yields }\end{array}$ & GDP & $\begin{array}{c}\text { Cyclical } \\
\text { position }\end{array}$ \\
\hline 0.70 & 0.57 & 0.61 & 0.45 & 0.57 \\
\hline
\end{tabular}

As can be seen from Table 2 above, the indicators were in the same cyclical position with global financial evolutions most of the time - the concordance varies between 45 percent of the time and 70 percent, whereas the local cyclical position (built out of the considered indicators) coincided with the cycle of global tensions in 60 percent of cases.

\subsection{Historical decomposition}

Historical decomposition was performed in Bayesian VARs estimated for each of the variables and the global tensions indicator. The prior specification for the Bayesian VAR was Normal-Wishart and I considered the Sigma matrix as univariate AR. Estimation was performed with the BEAR toolbox provided by ECB (Dieppe et al., 2018). The results of the analysis are presented in Figures 1-5.

As can be seen from Figure 1 below, shocks in loans to households own evolution appear to have been dominant. Still, during the economic and financial crisis, the shocks in global tensions were comparable in terms of impact. Moreover, in the more recent period, 2016q2 until 2018q3, global tensions have a predominant impact. 
The Impact of Global Tensions on the Economic and Financial Cycle in ... Andreea MURARU

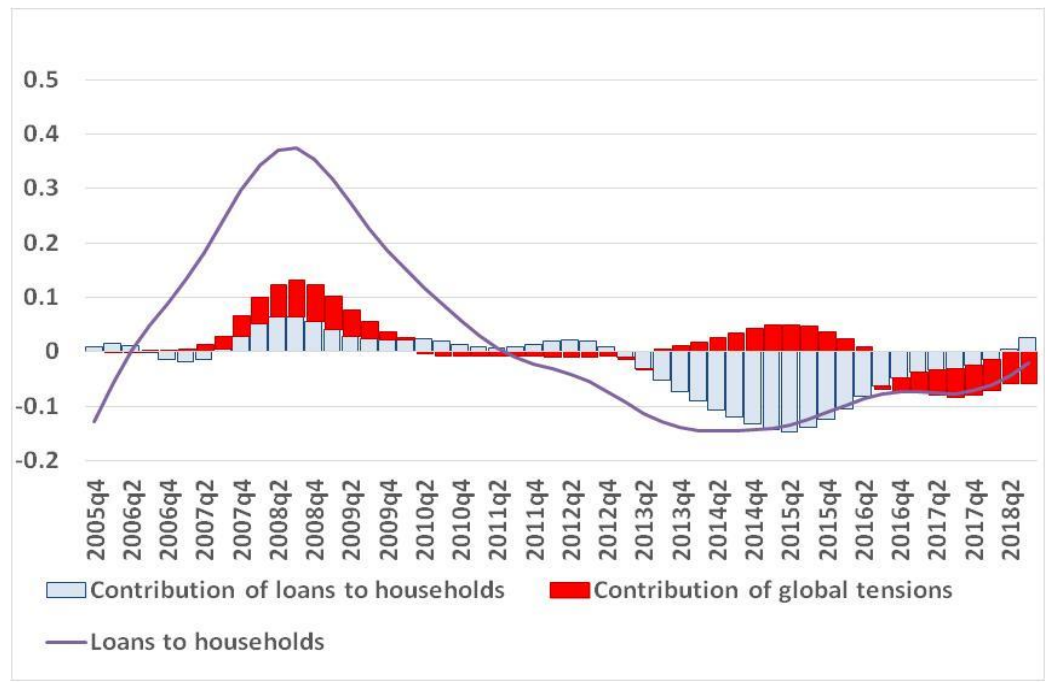

Figure 1. Historical decomposition - loans to households

Source: Author's own conception

For $10 \mathrm{Y}$ government bonds (Figure 2 below) the picture of historical decomposition says that global tensions were clearly dominant at times - at the peak of the economic and financial crises and also throughout 20132014.

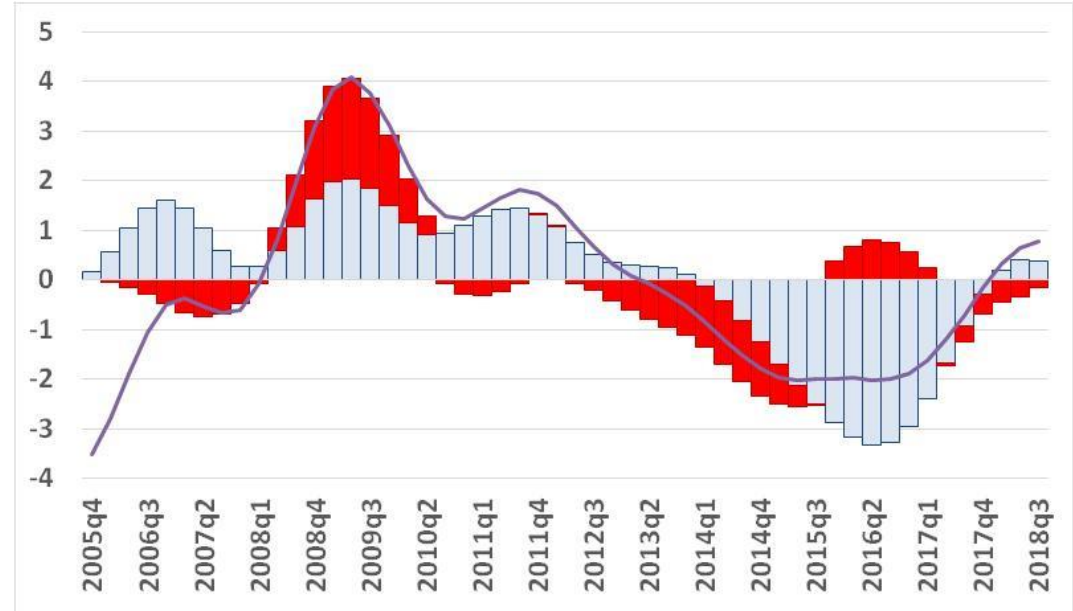

$\square$ Contribution of $10 \mathrm{Y}$ yields $\square$ Contribution of global tensions -10 Y yields

Figure 2. Historical decomposition - $10 \mathrm{Y}$ government bonds yield Source: Author's own conception 


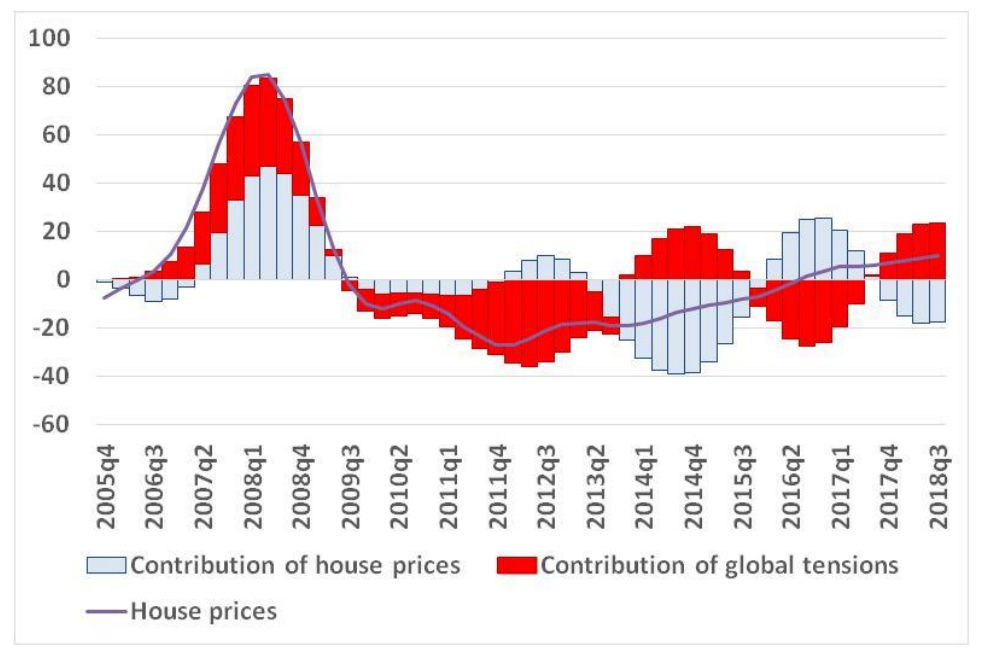

Figure 3. Historical decomposition - house prices

Source: Author's own conception

In what concerns house prices (Figure 3 above) but especially GDP and the cyclical position indicator (Figure 4 and Figure 5 below), the impact of global tensions is even higher, prevailing for long periods of time (starting at the beginning of the economic and financial crisis and ending in 2014) but still having a very important contribution in all other periods.

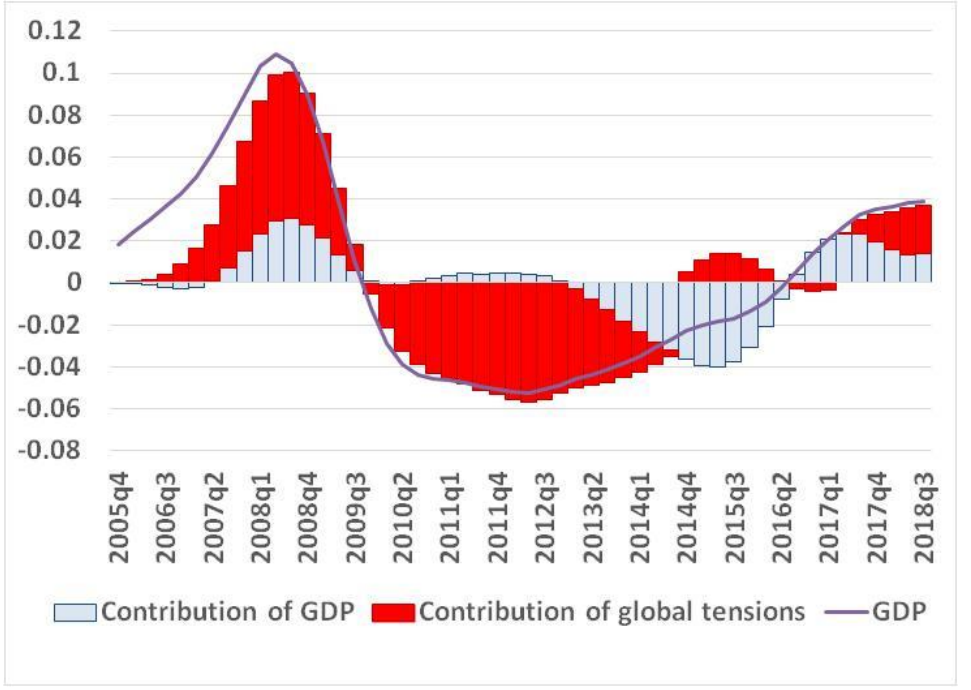

Figure 4. Historical decomposition - GDP

Source: Author's own conception 
The Impact of Global Tensions on the Economic and Financial Cycle in ... Andreea MURARU

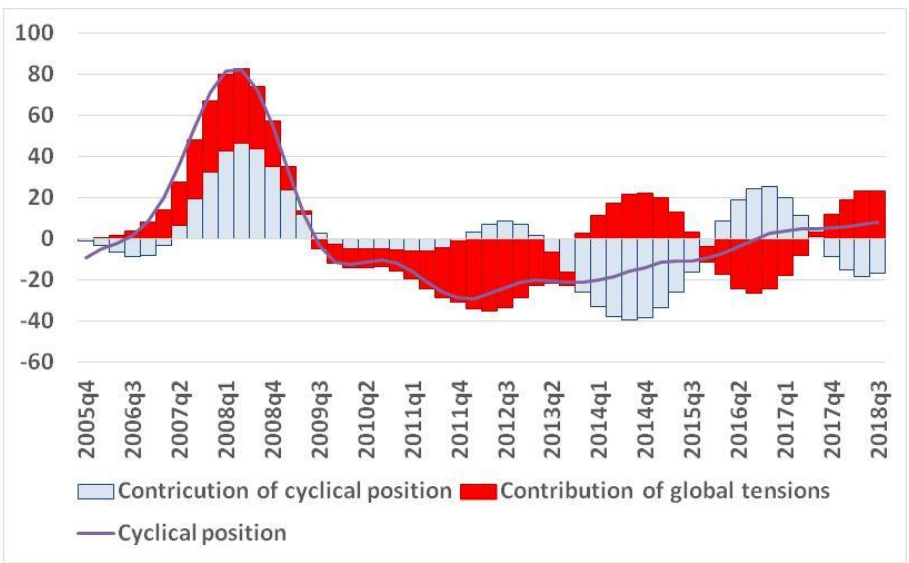

Figure 5. Historical decomposition - Cyclical position

Source: Author's own conception

\subsection{Wavelet coherence}

Wavelet coherence - I used the Matlab Cross Wavelet and Wavelet Coherence Toolbox provided free of charge by Grinsted (2004) - shows that, even though not constant throughout time, there is intense correlation between the selected variables and the measure of global tensions.
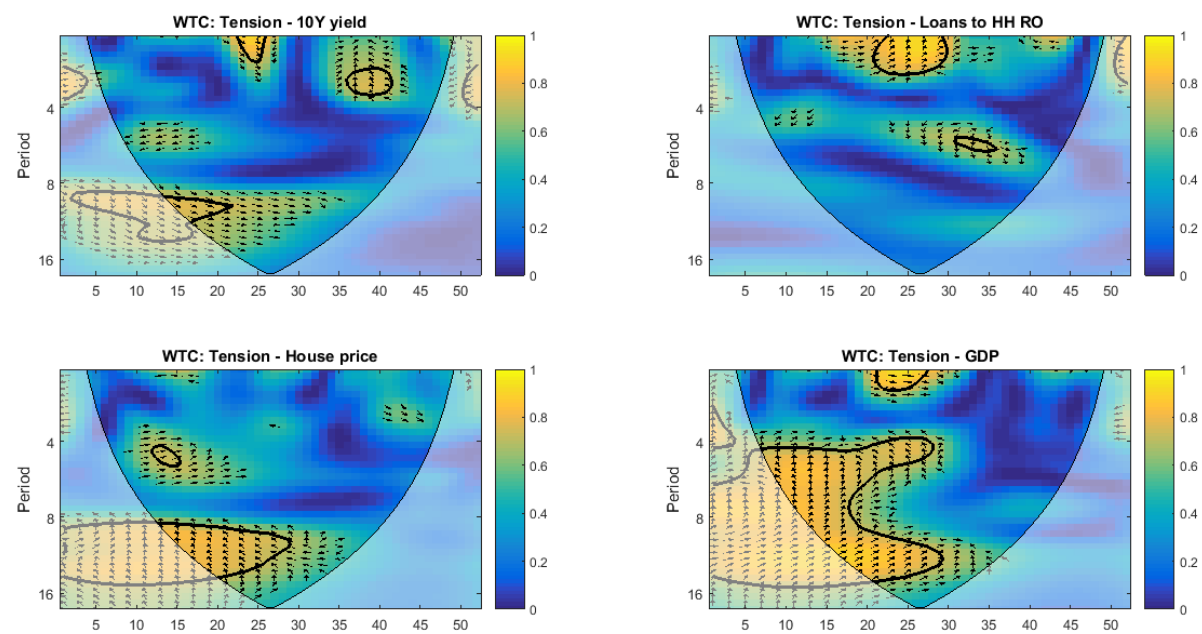

Figure 6. Wavelet coherence

Source: Author's own conception

As can be seen from Figure 6 above, the correlations happened mostly at a frequency of 8-12 quarters, with the exception of loans to 
households for which the correlation is sporadic, during the economic and financial crisis, and at a lower frequency. The results of wavelet coherence largely confirm the results of historical decomposition.

\section{Discussions}

The analyses in this paper showed the importance of the global context for local financial and economic developments. Still, the main limit of the study is the short data span. If in the VAR estimation the small sample was compensated by the use of Bayesian methods, the construction of cycles with long periods (30 years) is not yet possible.

\section{Conclusions}

In this paper I intended to investigate whether global tensions have an important impact on the evolution of the economic and financial cycle in Romania. By applying techniques specific to the financial cycle literature, I reached the conclusions that: financial variables for Romania are in the same cyclical position with the global tensions in 54 to 70 percent of the time, and that the local cyclical position coincided with the cycle of global tensions in 60 percent of cases. Moreover, the historical decomposition showed a high importance of global shocks for the evolution of the selected variables and for the cyclical position indicator. The correlation is, as expected, most intense during stress moments.

\section{References}

Aguiar-Conraria, L., \& Soares, M. (2014). The continuous wavelet transform: Moving beyond uni- and bivariate analysis. Joumal of Economic Surveys, 28, 344-375. https://doi.org/10.1111/joes.12012

Aguiar-Conraria, L., Azevedo, N., \& Soares, M. (2008). Using wavelets to decompose the time-frequency effects of monetary policy. Physica $A, 387$, 2863-2878. https://doi.org/10.1016/i.physa.2008.01.063

Aikamn, D., Haldane, A., \& Nelson B.D. (2015). Curbing the credit cycle. The Economic Journal, 125, 1072-1109. https://doi.org/10.1111/ecoj.12113

Aldasoro, I., Avdjiev, S., Borio, C., \& Disyatat, P. (2020). Global and domestic financial cycles: variations on a theme. BIS Working Papers, 864. https://www.bis.org/publ/work864.pdf

Benes, J., Laxton, D., \& Mongardini, J. (2016). Mitigating the deadly embrace in financial cycles; countercyclical buffers and loan-to-value limits. IMF Working Papers, 16/87. https://www.imf.org/en/Publications/WP/Issues/2016/12/31/Mitigatin 
The Impact of Global Tensions on the Economic and Financial Cycle in ... Andreea MURARU

g-the-Deadly-Embrace-in-Financial-Cycles-Countercyclical-Buffers-andLoan-to-Value-43860

Borio, C. (2014). Monetary policy and financial stability: what role in prevention and recovery? BIS Working Papers, 440.

https://www.bis.org/publ/work440.htm

Breitung, J., \& Eickmeier S. (2016). Analysing international business and financial cycles using multi-level factor models. In J. Hillebrand \& S.J. Koopman (Eds.) Advances in Econometrics, 35, (pp. 177-214). Emerald Insight. https://www.econstor.eu/bitstream/10419/98718/1/790216825.pdf

Boz, E., \& Tesar, L. (2019). The Global Financial Cycle. IMF Econ Rev 67, 1-3. https://doi.org/10.1057/s41308-019-00076-2

Bruno, V., \& Shin, H. S. (2015). Capital flows and the risk-taking channel of monetary policy. Journal of Monetary Economics, 71, 119-132. https://doi.org/10.1016/i.jmoneco.2014.11.011

Cazelles, B., Chavez, M., Berteaux, D., Menard, F., Vik, J., Jenouvrier, S., \& Stenseth, N. (2008). Wavelet analysis of ecological time series. Oecologia, 32(7), 287-304. https://doi.org/10.2307/40213251

Claessens, S., A., Kose, A., \& Terrones, M. (2011). Financial cycles: What? How? When?. Centre for Economic Policy Research Working Papers, 8379. https://EconPapers.repec.org/RePEc:cpr:ceprdp:8379

Claessens, S., A., Kose, A., \& Terrones, M. (2012). Journal of International Economics, 87(1), 178-190. https://doi.org/10.1016/j.jinteco.2011.11.008

Comunale, M. (2017). Synchronicity of real and financial cycles and structural characteristics in EU countries. Occasional Paper Series, 15. Bank of Lithuania. https://www.lb.lt/en/publications/no-15-synchronicity-of-realand-financial-cycles-and-structural-characteristics-in-eu-countries

Dées, S., \& Gales, A. (2019). The Global Financial Cycle and US Monetary Policy in an Interconnected World. Banque de France Working Papers, 744. https://publications.banque-france.fr/en/global-financial-cycle-and-usmonetary-policy-interconnected-world

Dieppe, A., van Roye, B., \& Legrand, R. (2018). The BEAR toolbox. https://www.ecb.europa.eu/pub/research/working-papers/html/beartoolbox.en.html

Drehmann, M., Borio, C., Gambacorta, L., Jiménez, G., \& Trucharte, C. (2010). Countercyclical capital buffers: exploring options. BIS Working Papers, 317. https://www.bis.org/publ/work317.htm

Drehmann, M., Borio, C., \& Tsatsaronis, K. (2011). Anchoring countercyclical capital buffers: the role of credit aggregates. BIS Working Papers, 355. https://www.bis.org/publ/work355.pdf 
Drehmann, M., Borio, C., \& Tsatsaronis, K. (2012). Characterising the financial cycle: don't lose sight of the medium term!. BIS Working Papers, 380. https://www.bis.org/publ/work380.htm

Engel, J. (2019). Business Cycle Dating Programs (BBQ). Matlab code. http://www.ncer.edu.au/resources/data-and-code.php

Gadanecz, B., \& Jayaram, K. (2016). Macroprudential policy frameworks, instruments and indicators: a review. In Irving Fisher Committee Bulletin No 41: Combining micro and macro statistical data for financial stability analysis. BIS. https://www.bis.org/ifc/publ/ifcb41c rh.pdf

Grinsted, A. (2004). Cross Wavelet and Wavelet Coherence Toolbox. http://www.glaciology.net/wavelet-coherence

Haavio, M. (2012). Financial Cycles and Business Cycles: Some Stylised Facts. Bank of Finland, BoF Online. https://helda.helsinki.fi/bof/handle/123456789/8432

Kunovac, D., Mandler, M., \& Scharnagl, M. (2018). Financial Cycles in Euro Area Economies: A Cross-Country Perspective. Working Papers. Croatian National Bank. https://bit.ly/2DbXEMe

Lutkepohl, H. (2011). Vector autoregressive models. EUI Working Papers. https://cadmus.eui.eu/bitstream/handle/1814/19354/ECO 2011 30.pdf

Miranda-Agrippino, S., \& Rey, H. (2020a). The Global Financial Cycle after Lehman. AE $A$ Papers and Proceedings, 110, 523-528. https://www.aeaweb.org/articles?id=10.1257/pandp.20201096

Miranda-Agrippino, S., \& Rey, H. (2020b). U.S. Monetary Policy and the Global Financial Cycle, The Review of Economic Studies, rdaa019. https://doi.org/10.1093/restud/rdaa019

Muraru, A. (2019). Co-movement and synchronicity of business and financial cycles in Romania and other EEMS. Proceedings of the IE 2019 International Conference, 453-458. https://bit.ly/3jnSrjF

Rünstler, G., \& Vlekke, M. (2016). Business, housing and credit cycles. ECB Working Paper, 1915. https://www.ecb.europa.eu/pub/pdf/scpwps/ecbwp1915.en.pdf

WGEM Team on Real and Financial Cycles. (2018). Real and financial cycles in EU Countries: stylised facts and modelling implications. ECB Occasional Paper, 205. https://www.ecb.europa.eu/pub/pdf/scpops/ecb.op205.en.pdf 


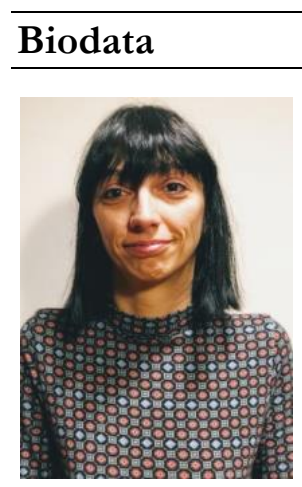

Andreea MURARU holds a $\mathrm{PhD}$ in Economic Cybernetics from the Bucharest Academy of Economic Studies (2012) and is $\mathrm{PhD}$ associate within the Department of Economic Cybernetics, The Bucharest Academy of Economic Studies. She has an MA degree in Finance (2007), graduated the Faculty of Economics, Babeş-Bolyai University in Cluj-Napoca, majoring Statistics (2005) and was ERASMUS-SOCRATES Student of Aristotle University, Thessaloniki.

Fields of Scientific Interest. multidimensional data analysis, econometrics and macroeconometrics, macroeconomic modeling, multidimensional time series analysis.

Scientific research activity: involvement in one research project with national financing; participant in national and international conferences and symposia; eleven published papers out of which four articles being published in ISI - Thompson Reuters journals. 